\title{
Predation of Nabis punctipennis on Acyrthosiphon pisum in the presence of the alternative prey Aphis craccivora in alfalfa
}

Depredación de Nabis punctipennis en Acyrthosiphon pisum en presencia de la presa alternativa Aphis craccivora en alfalfa

Verónica Campos Medina ${ }^{1}$, Jaime E. Araya ${ }^{2 *}$, and Francisco Zuazúa ${ }^{3}$

${ }^{1}$ Purdue University, Dept. Entomology, West Lafayette, Indiana 47905, USA. E-mail: camposvero@ gmail.com

2 Private Consultant. Formerly, Full Professor, Universidad de Chile, Casilla 1004, Santiago, Chile.

${ }^{3}$ Facultad de Ciencias, Escuela de Agronomía, Universidad Mayor, Campus Huechuraba, Camino La Pirámide 5750, Santiago, Chile.

*Corresponding author E-mail: jaimearaya@yahoo.com

\section{RESUMEN}

Se estudió la conducta de alimentación del depredador generalista Nabis punctipennis Blanchard (Nabidae) sobre Acyrthosiphon pisum Harris (Aphididae), dos hemípteros comunes en alfalfa en Chile, mediante un experimento en laboratorio utilizando A. pisum y Aphis craccivora Koch (Hemiptera: Aphididae) como presa alternativa, otro áfido común en alfalfa. La presencia de $A$. craccivora no afectó la depredación de A. pisum por $N$. punctipennis. La información obtenida sobre la conducta de depredación de $N$. punctipennis es valiosa para evaluar su potencial como agente de control biológico de A. pisum.

Palabras clave: Nabis punctipennis, Acyrthosiphon pisum, Aphis craccivora, nábido de alas punteadas, presa alternativa, control biológico.

\section{ABSTRACT}

The feeding behavior of the generalist predator Nabis punctipennis Blanchard (Nabidae) on Acyrthosiphon pisum Harris (Aphididae), two hemipterans common in alfalfa in Chile, was studied in a laboratory experiment using A. pisum, and Aphis craccivora Koch (Aphididae) as alternative prey, which is another common aphid in alfalfa. The presence of A. craccivora did not affect the predation of $A$. pisum by N. punctipennis. This finding on the predatory behavior of N. punctipennis is valuable to evaluate the potential of this nabid as a biological control agent of A. pisum.

Key words: Nabis punctipennis, Acyrthosiphon pisum, Alternative prey, Aphis craccivora, biological control, punctured-winged nabid. 


\section{INTRODUCTION}

When predation is evaluated with different preys at different ratios, the classical approach by Lucas et al. (1997) indicated four types of response: preference occurs for a prey type; there is no preference for preys; a switching behavior, when the predator consumes relatively more of the most abundant prey; and an anti-switching behavior, when the predator consumes relatively more of the least abundant prey.

Predation can be evaluated through functional responses (Schenk and Bacher, 2002; Fernández and Corley, 2004; Lee and Kang, 2004; Omkar and Pervez, 2004; Ma et al., 2005; Mandour et al., 2006; Sarmento et al., 2007). However, because of the polyphagous behavior of generalist predators, it is important to know their behavior as biological control agents in the presence of alternative prey (Ostman, 2004; Stiling and Cornelissen, 2005; Harwood and Obrycki, 2005; Tschanz et al., 2007; van Leeuwen et al., 2007) in order to assess their impact on control of the target prey.

An advantage of generalist predators over specialists is that the former can survive feeding on alternative prey when the target prey is absent, allowing them both early habitat colonization, and permanence in it (Ostman, 2004; Stiling and Cornelissen, 2005). In addition, presence of alternative prey can increase density of predators (Lester and Harmsen, 2002), improving biological control if a greater action on the target occurs, or reducing control of the pest if each predator decreases the attack rate on it. The increase or decrease depends on the preference of the predator for the available prey (Ostman, 2004). For example, both in the laboratory and field, Koss and Snyder (2005) found that the consumption of Leptinotarsa decemlineata (Say) (Coleoptera: Chrysomelidae) by Nabis spp. decreased in the presence of Myzus persicae (Sulzer) (Hemiptera: Aphididae) Thus, the polyphagous nature of the generalist predators poses some limits on their use as biological control agents.

Diverse generalist predators have resulted efficient for pest control (Symondson et al., 2002). In soybean field studies, Costamagna and Landis (2007) indicated that Harmonia axyridis (Pallas) and Coccinella septempunctata L. (Coleoptera: Coccinellidae) were the species that contributed most to predation of Aphis glycines L. (Hemiptera: Aphididae), and responded to changes in aphid density with increases both in abundance and per capita consumption.

A good understanding of predator/prey relationship allows developing successful biological control programs (Flores et al., 2010). Studies, like that conducted by Costamagna and Landis (2007), are important as they allow predicting the contribution of natural enemies to pest control so that farmers can trust these organisms and include them in pest control strategies (Zalucki et al., 2009).

The punctured-winged nabid Nabis punctipennis Blanchard can be an important aphid predator. In fact, it is widely distributed in alfalfa, and is among the most abundant predatory species in this crop (Artigas, 1994; Villarroel, 2001; Rebolledo et al., 2005). However, there is little research on the behavior of this nabid (Rebolledo et al., 2005). Therefore, further studies are required to analyze the feeding habits of this predator and determine how effective it can be at controlling aphids. It is important to note that using natural enemies in conservative biological control programs minimize the risks associated with the introduction of foreign species (i.e., in classical biological control) (Lavandero et al., 2006). The use of biological agents present in the crop to control pests has been widely reported in the literature. For example, studies conducted by Chang and Snyder (2004) on potato (Solanum tuberosum L.), Ostman (2004) on barley (Hordeum vulgare L.), and Cardinale et al. (2003) on alfalfa (Medicago sativa L.) showed that an increase in predator density results in a greater pest control.

In order to increase predator density, it is necessary to reduce limiting factors, such as insecticide use, and provide predators with the required sources of food. Adding shelters and secondary hosts to the system (Khan et al., 2008) can also help increase their lifespan and fecundity, and maximize their effect on pests. However, this can only be achieved when there is a good understanding of the ecology of the natural enemy and the community where it belongs (Johnsson et al., 2008).

The objective of this study was to evaluate under laboratory conditions the changes in predation by N. punctipennis of two common Aphididae pests of alfalfa, Acyrthosiphon pisum (target prey), and Aphis craccivora Koch (alternative prey).

\section{MATERIALS AND METHODS}

In this study, Nabis punctipennis Blanchard (Hemiptera: Nabidae) was offered to Acyrthosiphon pisum Harris and Aphis craccivora Koch (Aphididae) as target and alternative preys, respectively. Both aphids were collected from an alfalfa crop in the Metropolitan Region in central Chile. Presence of A. pisum is more stable during spring and at the end of summer, while $A$. craccivora increases its density close to the growing season, as described by Cardinale et al. (2003) in a study on alfalfa in the USA. In 
addition, Eubanks and Denno (2000) estimated the impact of a generalist predator on a prey population in experiments combining alternative preys the predator was exposed to in the field.

Rearing N. punctipennis and A. pisum. Adults of $N$. punctipennis were collected at the beginning of spring (October) in an alfalfa crop that was never treated with insecticides, in El Noviciado $(33.433333333333 \quad \mathrm{~N} \quad-70.716666666667 \quad \mathrm{E})$, Pudahuel, Metropolitan Region, Chile. Insects were placed in Petri dishes for $48 \mathrm{~h}$ to avoid natural enemies, and then were set free to obtain eggs in $50 \times 50 \times 50 \mathrm{~cm}$ transparent acetate cylinders covering potted white faba bean (Vicia faba L.) var. plants infested with $A$. pisum, and a cotton screen (Fig. 1), according to the methodology of Zuazúa et al. (2000) and Campos and Araya (2019). The nabid eggs inserted into the stems were placed in $12 \times 6,5 \times 17 \mathrm{~cm}$ transparent cages with humidified cotton, and kept at $24^{\circ} \mathrm{C}$ and a 14:10 h L:D regime. The emerging nymphs were placed individually in Petri dishes, maintained $2 \mathrm{~d}$ at $24^{\circ} \mathrm{C}$, and fed on aphids. Then, they were set free on $V$. faba plants with $A$. pisum in $50 \times 50 \times 50 \mathrm{~cm}$ cages covered with cotton screen at $22-28^{\circ} \mathrm{C}$. The nabids reached adulthood in $\sim 20 \mathrm{~d}$.

For the laboratory bioassays, only adult $N$. punctipennis females (1-15 d of age from the last molt) were obtained from the rearing cages. The nabids were placed in 350-mL transparent plastic vases with a $2 \mathrm{~cm}$ diameter orifice at the bottom, where a white sweet $V$. faba stem piece (approx. 12 $\mathrm{cm}$ long) with two apical leaflets was introduced (Romero et al., 2007). The opening around the stem was sealed with high density polyethylene foam, and the top of the container had a cloth lid. To keep the stem piece turgid and hydrated, this experimental arena (EA) was set on top of a $200 \mathrm{~mL}$ plastic container with drinking water (Campos, 2011), as shown in Fig. 1.

To homogenize their gut content, the nabids were previously fasted $24 \mathrm{~h}$ in Petri dishes, only with a humid cotton piece, in chambers at $24^{\circ} \mathrm{C}$ and a 14:10 L:D photoperiod. Then they were offered mixed diets of $A$. pisum (target prey) and A. craccivora (alternative prey). The prey were selected considering a homogeneous size, in the following ratios: 36/0,36/6, 36/16, 36/26, 36/36 per EA. A control treatment was included to determine natural mortality under the conditions already described, and consisted of an EA with 36 aphids of each species without a predator. After $24 \mathrm{~h}$, the predators were taken out of the EA, and the aphids of each species were counted on each of the treatments presented in Table 1. Both aphids had been collected earlier and reared separately in glass Flanders batteries on alfalfa branches that were renewed periodically, removing other insects with a hand vacuum cleaner to ensure the colonies were kept free of natural enemies.

Experimental design and statistical analysis. A completely randomized block design was used, each block with a replicate of each of the treatments, with 10 replicates. The numbers of dead prey at each prey ratio were analyzed with an ANOVA after verification of normal distribution, and the treatment differences were identified with the Tukey $(\mathrm{p} \leq 0.05)$ test, using the MINITAB 13.32 (Minitab Inc., 2000) statistic software.

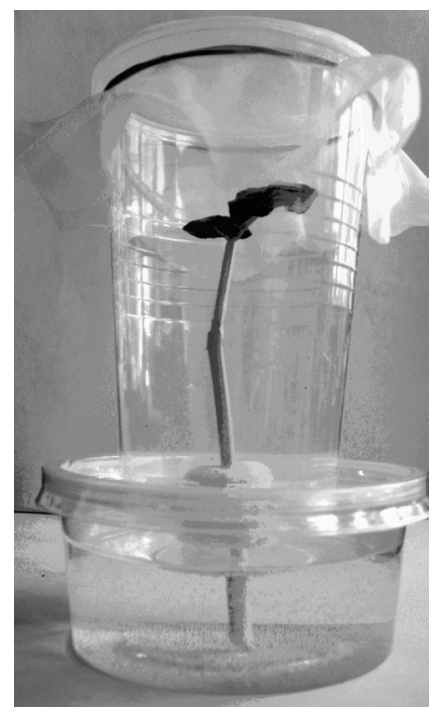

Fig. 1. Experimental arena (EA) on top of a plastic container with drinking water. 
Table 1. Treatments used in the experiment with target and alternative prey aphids.

\begin{tabular}{lccc}
\hline \multirow{2}{*}{ Treatments } & \multicolumn{3}{c}{ Number of insects per EA } \\
\cline { 2 - 4 } & Nabis punctipennis & Acyrthosiphon pisum & Aphis craccivora \\
\hline T1 & 1 & 36 & 0 \\
T2 & 1 & 36 & 6 \\
T3 & 1 & 36 & 16 \\
T4 & 1 & 36 & 26 \\
T5 & 1 & 36 & 36 \\
T6 (Control) & 0 & 36 & 36 \\
\hline
\end{tabular}

EA: Experimental arena.

Prey handling and search rate were determined using a curvilinear regression obtained by minimal squares with the Eviews 6 (QMS, 2007) statistic software, adjusted to Holling's (1959) disk equation:

$$
N a=\frac{T \times a \times N t}{1+(a \times h \times N t)}
$$

where $\mathrm{Na}=$ number of preys consumed by the predator; $N t=$ initial prey density; $T=$ experiment duration (24 h); $a=$ search rate; and $h=$ handling time.

\section{RESULTS AND DISCUSSION}

When varying the density of $A$. craccivora (alternative prey) in the EA and under a constant number of A. pisum (target prey), the consumption of the target prey remained constant despite the presence of the alternative prey (Table 2). This seems a preference response as described by Tschanz et al. (2007), who indicated that if a predator prefers a prey instead of another, or prey $B$, when the density of $B$ increases, the predation of the preferred prey is not necessarily reduced.

Regarding the other possible responses indicated by Lucas et al. (1997), if there is no preference between preys, it would be expected that the increase in density of one of these prey species results in a decrease in consumption of the other, and vice versa (Eubanks and Denno, 2000). As the replacement behavior cannot be determined with the experimental design used in our bioassay, it was not an objective of this study. In fact, the density of A. pisum remained constant, and only varied that of Ap. craccivora. This is in agreement with Eubanks and Denno (2000), who found that an increase in density of the alternative prey, eggs of Heliocoverpa zea Boddie (Lepidoptera: Noctuidae), did not affect the consumption of the target prey (A. pisum) by Geocoris punctipes (Say) (Heteroptera: Geocoridae). Due to the different mobility of both preys, they concluded that $G$. punctipes and other predators that can detect their prey visually can be used in biological control programs of mobile preys.

According to Provost et al. (2006), predators may select their prey actively or passively. This selection is passive when it is based on the physical or behavioral characteristics of the prey; and active, when the predator selects the prey according to its nutritious value.

Passive selection include characteristics of the prey, like size (Rashed et al., 2005; Provost et al. 2006), mobility (Eubanks and Denno, 2000; Provost et al., 2006), defense mechanisms (Provost et al., 2006), and color (Rashed et al., 2005).

Prey size is a key factor in predation; a larger prey species can be more easily detectable and be preferred due to its greater energetic value by the predator (Agusti et al., 2003). This factor may have had effects on our study since $A$. pisum is a relatively large $(\sim 3 \mathrm{~mm})$ aphid, while $A p$. craccivora measures only 1.5-2.2 mm (Artigas, 1994).

Prey mobility may also affect preferences for prey. In this sense, some predators prefer prey moving, while others predators like quiet prey (Eubanks and Denno, 2000). In our study, no differences were observed between both aphids in terms of mobility. Besides, no winged forms were used, that evidently are much more mobile.

Defense mechanisms were irrelevant since both aphids presented the same escape behavior, falling down when perceiving danger nearby, such as the presence of predators in the aerial parts of the plant, as described in previous studies (Lawrence et al., 1990; Rojas, 2005; Provost et al., 2006; Grez et al., 2007). Both species secreted alarm pheromones (Mandour et al., 2006).

The two aphid species used herein differ in coloration, light green in A. pisum (Artigas, 1994; Rojas, 2005), and brightly black in Aphis craccivora (Artigas, 1994).

Regarding active selection, the literature describes that $N$. punctipennis completed its development with both aphids. Thus, none of them is an alternative prey in terms of 
Table 2. Consumption means of Acyrthosiphon pisum and Aphis craccivora by Nabis punctipennis females during $24 \mathrm{~h}$ at $24^{\circ} \mathrm{C}$.

\begin{tabular}{|c|c|c|c|c|}
\hline \multicolumn{2}{|c|}{ Number of insects in the EA } & \multicolumn{3}{|c|}{ Mean consumption of prey \pm SD } \\
\hline $\begin{array}{l}\text { Acyrthosiphon } \\
\text { pisum }\end{array}$ & Aphis craccivora & $\begin{array}{l}\text { Acyrthosiphon } \\
\text { pisum }\end{array}$ & Aphis craccivora & TOTAL \\
\hline 36 & 0 & $7.4(0.816) \mathrm{a}$ & & $8.0(0.816) \mathrm{c}$ \\
\hline 36 & 6 & $7.0(1.826) \mathrm{a}$ & $2.9(1.370) \mathrm{b}$ & $9.9(2.132) b$ \\
\hline 36 & 16 & $6.6(1.838)$ a & $3.5(1.779) b$ & $10.1(2.846) b$ \\
\hline 36 & 26 & $6.5(1.269) \mathrm{a}$ & $6.0(1.563)$ a & $12.5(2.121) \mathrm{a}$ \\
\hline 36 & 36 & 7.1 (1.100) a & 7.3 (1.159) a & 14.4 (1.776) a \\
\hline
\end{tabular}

Means with different letters are significantly different, according to Tukey $(p<0.05)$ tests.

EA: Experimental arena.

nutrition since some authors consider a species as an alternative prey when a predator cannot complete its development and feeds on it under a mono specific diet (Soares et al., 2004). Therefore, it can be inferred that the nabid makes a passive selection. According to Hatano et al. (2008), aphid predators use physical signs like color and shape, and chemical ones like alarm pheromones to locate their prey at small distances.

The detection of prey by N. punctipenis would be enhanced by alarm pheromones. Thus, the nabid selects its prey by size. As mentioned before, larger prey is favorably perceived, and is also associated with a greater energetic value.

When consumption of Aphis craccivora increased with density, and under a constant consumption of $A$. pisum no increase occurred in total aphid consumption by the nabid (Fig. 2 ). The greatest daily consumption of adult $N$. punctipennis females in presence of two prey was $14.4 \pm 1.776$ aphids (Table 2). This is in agreement with Rebolledo et al. (2005), who determined that adults of $N$. punctipennis presented an average daily predatory capacity of $12.41 \pm 4.87$ aphids. However, in a study of the functional response the daily consumption was smaller, $7.7 \pm 0.949$ aphids (Campos and Araya, 2017).

The increase in consumption of the nabid in presence of two prey species can be explained by the fact that the encounter rate at high densities is greater, and predators eat much more than the minimum required (Omkar and Pervez, 2004). This occurs because the search rate increases and the generalist predators can adjust their predation rate to the density of the prey (van Leeuwen et al., 2007).

Another element to explain this increase in consumption, is that at high densities the predators do not consume totally each prey (Omkar and Pervez, 2004). Partial prey consumption represents an important energy cost for predators with extra oral digestion, like nabids, due to the loss of digestive enzymes injected to the prey. Thus, when evaluating the optimal consumption in energy, their capacity to extract nutrients of different quality has to be considered.

Compared with other generalist predators common in alfalfa, prey consumption is greater for coccinellids (Grez et al., 2007; Sarmento et al., 2007) than N. punctipennis, including Eriopis connexa (Germar), Adalia bipunctata (L.), and Hippodamia variegata (Goeze) (Coleoptera: Coccinellidae) (Zaviezo et al., 2004, 2006). However, nabids in alfalfa have a very dynamic presence (Zaviezo et al., 2004; Rebolledo et al., 2009). Thus, even though consumption per capita of the nabid is not too high, it has important characteristics, like being the predator most frequent in alfalfa in the Metropolitan Region (Villarroel, 2001). It is present during all growth stages of the crop, reaching a maximum density during spring from November through December (Romero et al., 2007). This is important for aphid control according to Ostman et al. (2003), and Ostman (2004), the predation of aphids early in the season is key for their control. According to Grez et al. (2010), maximum density of aphids in alfalfa in the central zone of Chile is reached during spring. This was also observed when collecting the material for this study, so it seems that $N$. punctipennis would be controlling the aphids in a key period for their control.

Considering our results, $N$. punctipennis would contribute to control of $A$. pisum mainly because it is a stable resource in alfalfa, present in key periods for control of this pest, and that can compensate its low per capita consumption with its abundance. Also noticeably was the conduct of $N$. punctipennis to the alternative prey Ap. craccivora, which did not affect the control of the target pest A. pisum, and that could even contribute positively to the control exerted by the nabid as it increases the numerical response of the 


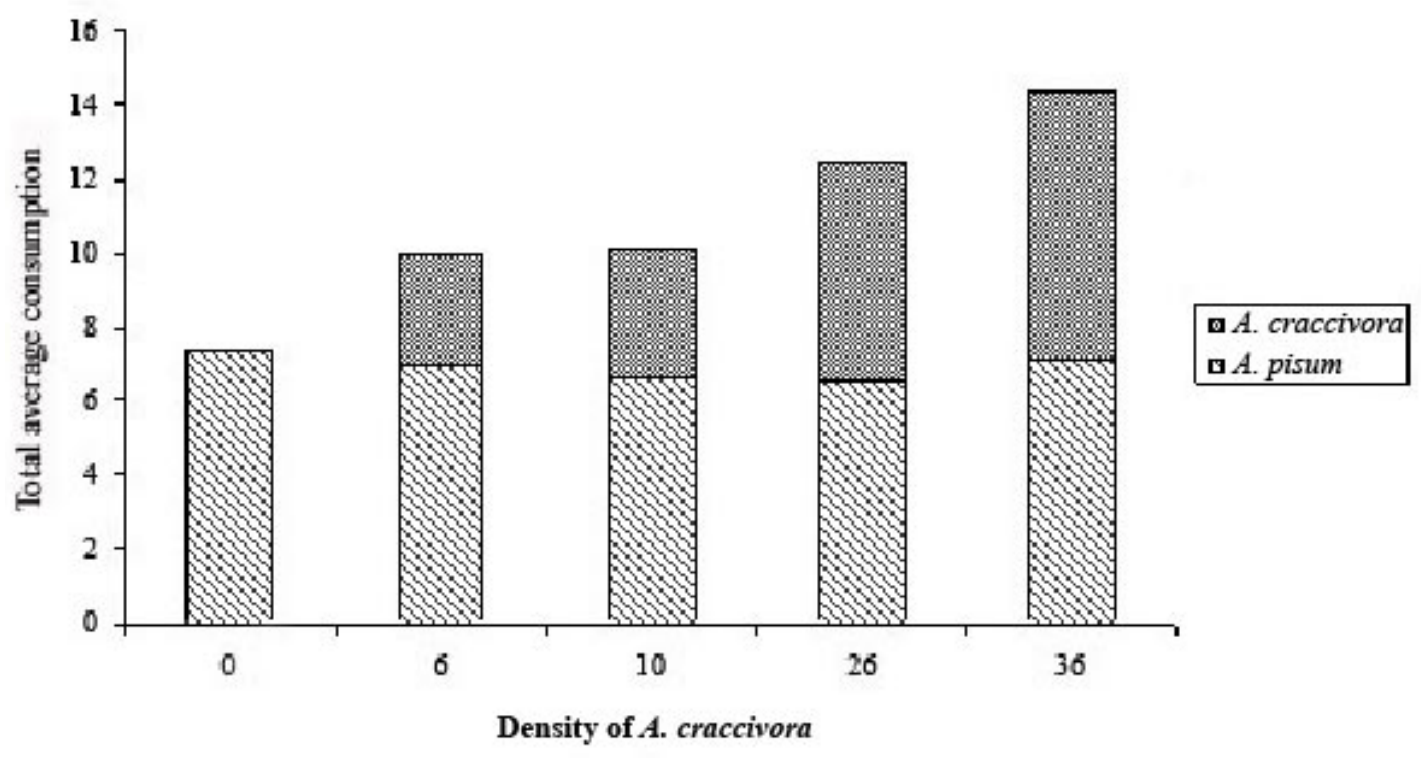

Fig. 2. Total average consumption of adult Nabis punctipennis females in presence of a constant density of Acyrthosiphon pisum (36 aphids per EA), and an increasing density of Aphis craccivora, during $24 \mathrm{~h}$ at $24^{\circ} \mathrm{C}$.

predator (Lester and Harmsen, 2002; Symondson et al., 2002). The same was found by Pons et al. (2005), when evaluating the numerical response of Nabis provencalis Remane (Hemiptera: Nabidae) they observed an increase in the abundance of the predator when aphid density increased in alfalfa. Also, Ostman (2004) found a direct relationship between the control of A. pisum and the presence of alternative prey, that he attributed to the fact that alternative prey, besides from influencing positively the reproductive rate of the generalist predators present, they can act attracting the predators to places where their density is greater, thus generating better control of A. pisum.

Further studies need to be conducted in order to evaluate the numerical response of predators. In this sense, Lester and Harmsen (2002) indicated that to estimate the efficiency of a predator as biological control agent, it is necessary to know its "total response", which includes functional and numerical responses, the migration rate of the predator in response to its own density, and the interference between predators.

The present study is a first step in understanding the predatory behavior of $N$. punctipennis, and provides key information on the predator-prey interaction with two aphid species commonly found in alfalfa. However, the simplified environment a predator is exposed to in the laboratory does not always permit predicting its efficiency as biological control agent in the field (Lester and Harmsen, 2002).
Therefore, field trials need to be conducted to confirm the results herein obtained under laboratory conditions. Furthermore, it might also be interesting to determine the effect of other alternative prey on predation by A. pisum. Alfalfa is an ecosystem with abundant and diverse species (Gerding and Devotto, 2000), and the impact of a generalist predator on prey depends not only on its abundance and susceptibility, but also on the populations of other pests that have the same enemy (Tschanz et al., 2007).

Nabid predators also consume larvae of Lepidoptera (Gitonga et al., 2002; Ma et al., 2005). Apart from A. pisum, N. punctipennis consume larvae of Crocidosema (Epinotia) aporema (Walsingham) (Lepidoptera: Tortricidae) (Prado, 1991), which is another frequent pest in alfalfa (Gerding and Devotto, 2000).

Along with evaluating the effect of other alternative prey, it is important to determine the effect of the presence of other predators (e.g. common ladybirds) on the control of A. pisum. A study in alfalfa conducted by Cardinale et al. (2003) reported synergism between predators and parasitoids in the control of A. pisum. These authors also described that when Nabis spp. coexisted with Harmonia axyridis (Pallas) (Coleoptera: Coccinellidae) and Aphidius ervi Haliday (Hymenoptera: Aphidiidae), the control of this aphid was greater than that exerted by each of the enemies separately, and also generated a higher production of alfalfa biomass. 
The role of alternative prey in sustaining predator populations has been widely reported. The availability of prey in the ecosystem is essential to evaluate how effective a predator can be at controlling pests (Harwood and Obrycki, 2005). For example, Harwood et al. (2007) conducted a study to determine prey consumed by O. insidiosus, and reported that this predator is an efficient control agent early in the season, when density of the aphid A. glycines is low. They also found the presence of the alternative prey Neohydatothrips variabilis (Kudo) (Thysanoptera: Thripidae) in the gut content of $O$. insidiosus.

Knowing the feeding habits of $N$. punctipennis in alfalfa would allow identifying prey preference when aphids are scarce, as observed when collecting the material used in this study (December and January). This would allow comparing those preys in behavior studies, to know better this frequent predator in this crop, and to determine its real potential as biological control agent.

It has been demonstrated that nabids respond numerically to several non-aphid preys (Pons et al., 2009). Therefore, the results obtained in our study under laboratory conditions need to be complemented with field trials to determine the efficiency of N. punctipennis as a biological control agent of aphids or other pests in Chilean alfalfa.

If $N$. punctipennis is an efficient predator, strategies could be developed to protect this nabid, as for example to prefer the use of insecticides like Spinosad, which affects it relatively less than other insecticides (Williams et al. 2003). Also, alfalfa could be grown in small plots that would favor beneficial insects, and according to Ostman et al. (2003), aphid density relates inversely with the borders of the crop.

\section{CONCLUSIONS}

The consumption of A. pisum by N. punctipennis was not affected in the presence of the alternative prey Aphis craccivora in alfalfa.

\section{LITERATURE CITED}

Agusti, N., S. Shayler, J. Harwood, J. Vaughan, K. Sunderland, and W. Symondson. 2003. Collembola as alternative prey sustaining spiders in arable ecosystems: prey detection within predators using molecular markers. Molecular Ecology 12:3467-3475.

Artigas, J. 1994. Entomología económica: insectos de interés agrícola, forestal, médico $\mathrm{y}$ veterinario (nativos, introducidos $\mathrm{y}$ susceptibles de ser introducidos). 943 p. Ediciones Universidad de Concepción, Concepción, Chile.
Campos, V. 2011. Conducta de depredación de Nabis punctipennis Blanchard (Hemiptera: Nabidae) sobre dos especies de áfidos de la alfalfa. 40 p. Memoria Ingeniero Agrónomo $\mathrm{y}$ tesis Mg. Sc. Facultad de Ciencias Agronómicas, Universidad de Chile, Santiago, Chile.

Campos, V., and J.E. Araya, 2017. Functional response of Nabis punctipennis Blanchard (Hemiptera: Nabidae) to Acyrthosiphon pisum Harris (Hemiptera: Aphididae) on alfalfa. Chilean Journal of Agriculture and Animal Science 33(1):64-72.

Cardinale, B., C. Harvey, K. Gross, and A. Ives. 2003. Biodiversity and biocontrol: emergent impacts of a multi-enemy assemblage on pest suppression and crop yield in an agroecosystem. Ecology Letters 6:857-865.

Chang, G., and W. Snyder. 2004. The relationship between predator density, community composition, and field predation of Colorado potato beetle eggs. Biological Control 31:453461.

Costamagna, A., and D. Landis. 2007. Quantifying predation on soybean aphid through direct field observations. Biological Control 42:16-24.

Eubanks, M., and R. Denno. 2000. Health food versus fast food: the effects of prey quality and mobility on prey selection by a generalist predator and indirect interactions among species. Ecological Entomology 25:140-146.

Fernández, V., y J. Corley. 2004. La respuesta funcional: una revisión y guía experimental. Ecología Austral 14:83-93.

Flores, A., S. Rodríguez, M.G. Ramos, y F. Payán. 2010. Estudio de Harmonia axirydis Pallas (Coleoptera: Cocinelidae) como bioagente de control de Aphis gossypii Glover (Hemiptera: Aphididae). Interciencia 35(7):506-509.

Gerding, M., y L. Devotto. 2000. Plagas de la alfalfa. p. 109-125 p. En Soto, P. (ed.) Alfalfa en la zona centro sur de Chile. INIA, Chillán, Chile.

Gitonga, L., W.A. Overholt, B. Lohr, J.K. Magambo, and J.M. Mueke. 2002. Functional response of Orius albidipennis (Hemiptera: Anthocoridae) to Megalurothrips sjostedti (Thysanoptera: Thripidae). Biological Control 24:1-6.

Grez, A., P. Rivera, and T. Zaviezo. 2007. Foliar and ground-foraging predators of aphids associated with alfalfa crops in Chile: are they good or bad partners? Biocontrol Science and Technology 17(10):1071-1077.

Grez, A., C. Torres, T. Zaviezo, B. Lavandero, and M. Ramírez. 2010. Migration of coccinellids to alfalfa fields with varying adjacent vegetation in Central Chile. Ciencia e Investigación Agraria (Chile) 37(2):111-121. 
Harwood, J.D., N. Desneux, H.J.S. Yoo, D.L. Rowley, M.H. Greenstone, J.J. Obrycki, and R. J. O'Neil. 2007. Tracking the role of alternative prey in soybean aphid predation by Orius insidiosus: a molecular approach. Molecular Ecology 16(2):4390-4400.

Harwood, J., and J. Obrycki. 2005. The role of alternative prey in sustaining predator populations. p. 453-462. In $2^{\text {nd }}$ Int. Symposium on Biol. Control of Arthropods. September 12-16, 2005. Davos, Switzerland.

Hatano, E., G. Kunert, J.P. Michaud, and W. Weisser. 2008. Chemical cues mediating aphid location by natural enemies. European Journal of Entomology 105:797-806.

Hosseini1, R., O. Schmidt, and M.A. Keller. 2012. Detection of predators within Brassica crops: A search for predators of diamondback moth (Plutella xylostella) and other important pests. African Journal of Agricultural Research 7(23):3473-3484.

Johnsson, M., S. Wratten, D. Landis, and G. Gurr. 2008. Recent advances in conservation biological control of arthropods by arthropods. Biological Control 45:172-175.

Khan, Z., D. James, C. Midega, and J. Pickett. 2008. Chemical ecology and conservation biological control. Biological Control 45:210224.

Koss, A., and W. Snyder. 2005. Alternative prey disrupt biocontrol by a guild of generalist predators. Biological Control 32:243-251.

Lavandero, B., C. Muñoz, y W. Barros. 2006. El talón de Aquiles del control biológico: una visión para su éxito. Agro-Ciencia 22(2):111123.

Lawrence, D., A. Fraser, and B. Roitberg. 1990. The economics of escape behaviour in the pea aphid, Acyrthosiphon pisum. Oecologia 83:473-478.

Lee, J., and T. Kang. 2004. Functional response of Harmonia axyridis (Pallas) (Coleoptera: Coccinellidae) to Aphis gossypii Glover (Homeptera: Aphididae). Biological Control 31:306-310.

Lester, P., and R. Harmsen. 2002. Functional and numerical responses do not always indicate the most effective predator for biological control: an analysis of two predators in a two-prey system. Journal of Applied Ecology 39:455-468.

Lucas, E., D. Coderre, and C. Vincent. 1997. Voracity and feeding preferences of two aphidophagous coccinellids on Aphis citricola and Tetranychus urticae. Entomologia Experimentalis et Applicata 85:151-159.
Ma, J., Y. Li, M. Keller, and S. Ren. 2005. Functional response and predation of Nabis kinbergii (Hemiptera: Nabidae) to Plutella xylostella (Lepidoptera: Plutellidae). Insect Science 12:281-286.

Mandour, N., N. El-Basha, and T. Liu. 2006. Functional response of the ladybird, Cydonia vicinanilotica to cowpea aphid, Aphis craccivora in the laboratory. Insect Science 13:49-54.

Minitab Inc. 2000. Minitab version 13.23. State College, Pennsylvania, USA.

Omkar, P.A., and A. Pervez. 2004. Functional and numerical responses of Propylea dissecta (Col., Coccinellidae). Journal of Applied Entomology 128:140-146.

Ostman, O. 2004. The relative effects of natural enemy abundance and alternative prey abundance on aphid predation rates. Biological Control 30:281-287.

Ostman, O., B. Ekbom, and J. Bengtsson. 2003. Yield increase attributable to aphid predation by ground-living polyphagous natural enemies in spring barley in Sweden. Ecological Economics 45:149-158.

Pons, X., B. Lumbierres, and R. Albajes. 2009. Heteropterans as aphid predators in intermountain alfalfa. European Journal of Entomology 106:369-378.

Pons, X., E. Núñez, B. Lumbierres, and R. Albajes. 2005. Epigeal aphidophagous predators and the role of alfalfa as a reservoir of aphid predators for arable crops. European Journal of Entomology 102:519-525.

Prado, E. 1991. Artrópodos y sus enemigos naturales asociados a plantas cultivadas en Chile. 207 p. Boletín Técnico 169. INIA, Santiago, Chile.

Provost, C., E. Lucas, and D. Coderre. 2006. Prey preference of Hyaliodes vitripennis as an intraguild predator: Active predator choice or passive selection? Biological Control 37:148-154.

QMS. 2007. Quantitative Micro Software (QMS). Eviews 6. User's Guides I and II. Irvine, California, USA.

Rashed, A., C. Beatty, M. Forbes, and T. Sherratt. 2005. Prey selection by dragonflies in relation to prey size and wasp-like colours and patterns. Animal Behaviour 70:1195-1202.

Rebolledo, R., J. Sheriff, L. Parra, and A. Aguilera. 2009. Life, seasonal cycles, and population fluctuation of Hippodamia variegata (Goeze) (Coleoptera: Coccinellidae), in the central plain of La Araucanía Region, Chile. Chilean Journal of Agriculture Research 6(2):292-298. 
Rebolledo, R., R. Villegas, C. Klein, y A. Aguilera. 2005. Fluctuación poblacional y capacidad depredadora de Nabis punctipennis Blanchard (Hemiptera: Nabidae). Agricultura Técnica (Chile) 65(4):442-446.

Rojas, S. 2005. Control biológico de plagas en Chile, historia y avances. 123 p. INIA, Santiago, Chile.

Romero, C., J. Araya, M.A. Guerrero, T. Curkovic, y E. Viñuela. 2007. Biología del depredador generalista Nabis punctipennis Blanchard (Hemiptera: Nabidae). Phytoma (España) 191:36-44.

Sarmento, R., A. Pallini, M. Venzon, F. Fonseca de Souza, J. Molina-Rugama, and C. Lima de Oliveira. 2007. Functional response of the predator Eriopis connexa (Coleoptera: Coccinellidae) to different prey types. Brazilian Archives of Biology and Technology 50:121-126.

Schenk, D., and S. Bacher. 2002. Functional response of a generalist insect predator to one of its prey species in the field. Journal of Animal Ecology 71:524-531.

Soares, A., D. Coderre, and H. Schanderl. 2004. Dietary self-selection behaviour by the adults of the aphidophagous ladybeetle Harmonia axyridis (Coleoptera: Coccinellidae). Journal of Animal Ecology 73:478-486.

Stiling, P., and T. Cornelissen. 2005. What makes a successful biocontrol agent? A meta-analysis of biological control agent performance. Biological Control 34:236-246.

Symondson, W., K. Sunderland, and M. Greenstone. 2002. Can generalist predators be effective biocontrol agents? Annual Review of Entomology 47:561-594.
Tschanz, B., L. Bersier, and S. Bacher. 2007. Functional responses: a question of alternative prey and predator density. Ecology 88(5):1300-1308.

Van Leeuwen, E., V. Jansen, and P. Bright. 2007. How population dynamics shape the functional response in a one-predator-twoprey system. Ecology 88(6):1571-1581.

Villarroel, J. 2001. Efecto de metamidofos, lambdacihalotrina, spinosad y thiacloprid sobre Nabis spp. (Hemiptera: Nabidae). 55 p. Memoria Ingeniero Agrónomo. Facultad de Ciencias Agronómicas, Universidad de Chile, Santiago.

Williams, T., J. Valle, and E. Viñuela. 2003. Is the naturally derived insecticide Spinosad $\AA$ compatible with insect natural enemies? Biocontrol Science and Technology 13(5):459475.

Zalucki, M, D. Adamson, and M. Furlong. 2009. The future of IPM: whither or wither? Australian Journal of Entomology 48:85-96.

Zaviezo T., A. Grez, y D. Donoso. 2004. Dinámica temporal de coleópteros asociados a alfalfa. Ciencia e Investigación Agraria 31:29-38.

Zaviezo, T., A. Grez, C. Estades, and A. Pérez. 2006. Effects of fragmentation and isolation on the density, species richness and distribution of ladybeetles in manipulated alfalfa landscapes. Ecological Entomology 31:646-656.

Zuazúa, F., J.E. Araya, and M.A. Guerrero. 2000 Método de crianza de Aphidius ervi (Hymenoptera: Aphididae) sobre Acyrthosiphon pisum (Homoptera: Aphididae). Bol. San. Veg., Plagas 26(3):433437. 